\title{
Transmutations of the Green World
}

\author{
Inga-Stina Ewbank
}

\section{Q OpenEdition}

\section{Journals}

Electronic version

URL: http://journals.openedition.org/shakespeare/1301

DOI: 10.4000/shakespeare.1301

ISSN: 2271-6424

\section{Publisher}

Société Française Shakespeare

\section{Printed version}

Date of publication: 1 November 1995

Number of pages: 121-133

\section{Electronic reference}

Inga-Stina Ewbank, "Transmutations of the Green World ", Actes des congrès de la Société française Shakespeare [Online], 13 | 1995, Online since 01 January 2007, connection on 06 May 2019. URL : http://journals.openedition.org/shakespeare/1301; DOI : 10.4000/shakespeare.1301 


\title{
SHAKESPEARE \\ LE MONDE VERT : RITES ET RENOUVEAU
}

Société Française Shakespeare

\author{
Actes du Congrès 1994 \\ sous la direction \\ de \\ M.T. JONES-DAVIES
}

Ouvrage publié avec le soutien de

BARCLAYS

BARCLAYS BANK S.A.

PARIS

LES BELLES LETTRES

1995 
Tous droits de traduction, de reproduction et d'adaptation réservés pour tous les pays.
(C) 1995 Société d'édition Les Belles Lettres, 95 bd Raspail 75006 Paris 


\section{Transmutations of the Green World : Re-writing As You Like It}

For those of us schooled on the work of C. L. Barber and Northrop Frye, the phrase 'Shakespearian comedy' is probably forever linked in our minds with 'green worlds', 'idiotes figures', and 'transformed societies'.

In the words quoted above, Jean E. Howard introduces a paper challenging the way "Frye and Barber taught an entire generation of Shakespearian critics a way of comprehending Shakespeare's comic practice"1. My aim, though in the same direction, is more modest : to draw attention to two mid-nineteenth-century dramatisations of the 'green world' of As You Like It, each conceived as part of a campaign to show that the contemporary theatre had been mistaken in valuing only the tragedies of Shakespeare and yet both also providing, on examination, something of a challenge, however indirect and by default, to mid- and latetwentieth century orthodoxies in regard to Shakespeare's comic practice.

In September 1855 a version of As You Like It, entitled Livet i Skoven (Life in the Forest) and prepared by Sille Beyer, a Danish woman writer and translator, was staged at the Norwegian Theatre in Bergen. For the theatre's young stage instructor, Henrik Ibsen, it was to be his one and only contact with Shakespeare in so far as this was Shakespeare - in a directorial capacity. A few months later, in April 1856, George Sand's Comme il vous plaira opened at the Comédie-Française ${ }^{2}$. The absence of that theatre's great tragedienne, Rachel, on tour in London and America, had created a breathing-space in the repertoire and George Sand had availed herself of it for her adaptation of As You Like It.

There is no direct connection between between these two rewritings of Shakespeare's play. The Sille Beyer piece antedates George Sand's by seven years ${ }^{3}$, and the famous Frenchwoman is hardly likely to have taken note of a Danish attempt on the Shakespearean text which, in her Preface to Comme il vous plaira, she calls 'le plus doux de ses drames romanesques' (p. 118). But in 
the two virtually contemporary plays, written by two women from two different cultural and social contexts and theatrical traditions, there are interesting similarities in the way Shakespeare's green world has been re-invented. And the interest is not merely historical.

It is very easy to scoff at attempts made in earlier periods to come to terms with Shakespeare, and particularly when they involve such major departures from the original as do these two pieces. Yet, I find, a closer examination of such activitities often means that scoff turns into a curious kind of respect. Partly, no doubt, this is a reaction against the current exclusivity and dogmatism of certain theoretical stances in the approach to Shakespeare. Partly it is an adherence to the kind of positive scepticism about 'real' (or, indeed, 'alternative') Shakespeare which T. S. Eliot articulated long ago:

About anyone so great as Shakespeare, it is probable that we can never be right; and if we can never be right, it is better that we should from time to time change our way of being wrong 4 .

My point is not that these versions of As You Like It have got it 'right', but that their ways of being 'wrong' help to illuminate aspects - qualities and potentials - of the original which may be obscured or denied if we see it through the frame established by Northrop Frye.

It must be said at once that neither of the two plays are masterpieces, and that it would be all too easy to use As You Like It as a stick to beat them with. But they were both serious attempts at rewriting Shakespeare for a contemporary stage and audience. In what amounts to a progamme declaration, in the form of a prefatory letter to A. M. Régnier, director of the ComédieFrançaise, George Sand claims no definitiveness for her 'essai', only boldness in 'daring' to produce a first French stage version of As You Like It (p. 121). She clearly saw herself as a mediator of Shakespeare ; and in a letter inviting Macready to come and see her play - he attended a dress rehearsal and was not impressed she writes that "malgré les arrangements que je crois nécessaires à notre scène moderne française, j'espère avoir conservé les

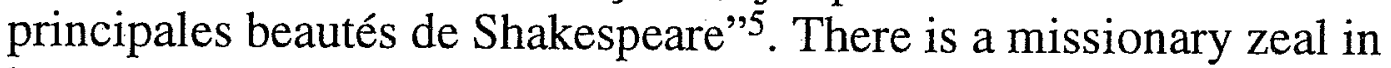
her account of the reception of his/her 'beautés' : 
Excellent succès de Comme il vous plaira, malgré Ia résistance et l'hostilité preparées, tout cela a été muet, et le public a été forcé de trouver que Shahkespeare [sic] n'était pas une bête ${ }^{6}$.

And, though another letter suggests a more qualified success (and accurately so, as the play seems to have made little impact on the history of Shakespeare in France), nevertheless "Shakespeare a triomphé plus que je n'y comptais"7. Sille Beyer's version also had a mixed reception, though some reviewers praised it unreservedly, and even those who regretted having to put up with an adaptation, rather than a straight translation, also admitted that Life in the Forest was more suited to a Danish audience and stage than $A s$ You Like It, "a bold Anglo-Saxon piece, written for a bold AngloSaxon public" and "not accessible to the modern dramatic or theatrical consciousness" 8 . And though voices - Ibsen's among them - were to be raised in favour of putting on 'real' Shakespeare, Sille Beyer's piece held the stage both in Denmark and in Norway until the late $1870 \mathrm{~s}^{9}$.

To call these adaptations 'serious' is to say that they are not like the medley by Charles Johnson called Love in a Forest which ran for six nights at Drury Lane in 1723, and where a skeleton of As You Like It was fleshed out by a selection of favourite passages from other Shakespeare plays. In Act I the wrestling between Charles and Oliver borrows heavily from the language around the abortive combat in Richard II ; in Act IV Viola's speech 'She never told her love' is inserted into the dialogue between Rosalind and Orlando; Act V consists largely of the Pyramus and Thisbe interlude from A Midsummer Night's Dream, represented before the Duke while Rosalind changes into a dress, and so on. The only thing that this cannibalistic 'version' has in common with the two under discussion is that Jacques and Celia fall in love and marry (Johnson's Oliver having killed himself in remorse offstage).

Unlike Johnson, both Sille Beyer and George Sand are genuinely concerned to transpose the play into terms acceptable to contemporary stage practice. George Sand devotes much of her Preface to lamenting the impossibility of a faithful rendering when the theatre demands 'habilité' and 'actualité'. Without mentioning Scribe by name, she deplores the tyranny of the 'well-made' play : Shakespeare, she knows, works by combining realism ('actualité') and imagination, magic, lyricism. Regretfully she admits that she has had to concentrate on that in the play which is accessible to 
'raison' - 'cette raison française dont nous sommes si vains et qui nous prive de tant d'originalités non moins precieuses' - and so she has had to amend 'le desordre de 1a composition' of this 'génie sauvage' (pp. 119, 118).

Scribe was also the most frequently performed playwright in the mid-nineteenth-century Danish (and Norwegian) theatre ; and, interestingly, while George Sand is reacting against his hegemony, Sille Beyer is doing her best to re-write Shakespeare in the mode of his comédies-vaudevilles. She wrote Life in the Forest from the depth of her involvement with the pair that wielded a tremendous influence over the Royal Theatre in Copenhagen : Johan Ludvig Heiberg, philosopher, writer (with a particular line in vaudevilles) and director of the Theatre from 1849 to 1856 , and his wife, Johanne Louise Heiberg, for decades the Royal Theatre's leading actress. For her Sille Beyer wrote the part of Celia (as she had already turned Twelfth Night into Viola and was to turn All's Well That Ends Well into The King's Physician). And she dealt with the play as a whole in obeyance of the male Heiberg's principle that a theatre that has known Holberg and Scribe can accept Shakespearean comedy only after 'considerable modifications' in structure as well as speech modes ${ }^{10}$.

The anxiety to adapt to the theatre of the period resulted, in the case of Life in the Forest, in four acts of prose and blank verse, interspersed with songs; while Comme il vous plaira consists of three acts of prose ${ }^{11}$. Each act, of course, has its own scenery ${ }^{12}$. The green world is partly translated out of English into painted cloth. The stage directions for the second act of Comme il vous plaira, for example, demand an elaborate forest scene in three planes, with rocks, great oaks and a steep hillock. Act 3 is set in front of Jacques's dilapidated castle, 'un pavillon de pauvre apparence' surrounded by ruins : 'On est sur un site élevé et pittoresque' (SD, p.184). The visual effects are thematically important : they interact with, not to say dominate, characters whose sensitivity is measured by their response to the beauties of nature. Thus George Sand's Jacques (who is really her leading character) has a soliloquy - 'O nature! toi seule parles une langue vraie' (p.168) - in which he expounds the impact of nature on the mind, accompanied from offstage by 'un air simple et rustique'.

In one sense, then, these plays are much greener than Shakespeare's. The contrast brings home, forcibly, how much Shakespeare's landscape is one of people, and how utterly his 
green world is created by the language of a vast array of characters, displaying a range of attitudes in confrontational dialogues, often overheard by one or two others. Shakespeare's green world is not in trees and ruins but in what people say and do, as social order and sexual difference are confounded : the Forest of Arden as seen by Touchstone and by Corin ; a place for love as seen by Orlando and Rosalind (and by Rosalind both in and out of disguise), by Silvius and Phoebe, Touchstone and Audrey. It is a space where the Romantic raptures of George Sand's Jacques would immediately have been mocked as attitudinising, even as Duke Senior's much more moderate delight over sermons in stones is gently questioned by Amiens' response :

Happy is your grace

That can translate the stubbornness of fortune

Into so quiet and so sweet a style. (AYLI, 2.1.18-20)

Neither adaptation aims at the creation of such a complex space. The Shakespearean range of characters is much forshortened in both. Comme il vous plaira has neither the real shepherd Corin, nor the pastoral pair of Silvius and Phoebe. In Life in the Forest Corin is an amalgamation of the character of that name with Shakespeare's Silvius; he suffers from unrequited love and weeps whenever he appears. The object of his love is Grissel, who is in turn a combination of Audrey and Phoebe, with lines from both parts ; and Touchstone, who acts as a rather serious master of ceremonies throughout the play, never enters into any amorous relationship with her.

Such changes are, of course, symptoms of more radical structural and conceptual changes. Both plays open in the court of the usurping Duke, move out into the Ardennes, where the good Duke is in exile, and end on a restitution and return to court civilization. In that sense they would appear to follow what Northrop Frye describes as 'the rhythmic movement from normal world to green world and back again'13. But in the interest of a logically coherent plot — 'habilité' and 'raison' - the 'rhythmic' pattern of As You Like It - saturnalian release, followed by reaffirmation of order - has been transmuted into one of political intrigue and of carefully motivated behaviour in a handful of plausible characters. Anything irrational - such as Hymen disappears from both structures, and anything ritualised - such as Rosalind's giving herself away - from both texts. The two Dukes 
play a far more prominent part than they do in Shakespeare's play. The green world is not one of saturnalian freedom but a place of retreat and contemplation where one learns to be a good ruler and a good citizen.

Morally, Shakespeare's plot is one of his 'mouldy tales' in which good and evil are données : 'my soul - yet I know not why - hates nothing more than he', says Oliver of Orlando. The double set of good and evil brothers is central to the fairytale pattern of the play. In Life in the Forest there is only one villain, the usurping Duke, who is also Orlando's evil guardian. In this version Oliver has already joined the exiled Duke in the forest, where he has also absorbed the part of Shakespeare's Jacques, the seven ages speech and all. In Comme il vous plaira Oliver (here Olivier) is still the wicked brother, but he never repents and reforms. Instead he arrives with some of his men, towards the end of the play, to accuse Orlando (here Roland) of treason, thus providing the good Duke with a chance to test his son-in-law to be : he disproves the accusation, condemns Olivier to death and watches Roland plead, out of brotherly love, for the life of his former oppressor.

The ending of Sille Beyer's play is dominated by the political framework, not by the loving couples. We learn that the reason why Duke Senior (here Robert) went into exile originally was to prevent a civil war between his own supporters and those of his brother (here Duke Philip). There is now a revolt in the country : the people want Duke Robert reinstated. To prevent this happening, Philip enters with an army; but, betrayed by his own followers and saved by Orlando from being killed by a wild boar (not a lion!), has a change of heart and appears in the final scene to hand the ducal crown back to Robert: 'In the shelter of these trees I found my own self, / And found my peace again' (p.90). Offstage, at this point, are heard alarums and calls for Duke Robert, who then decides that

They are my people, my compatriots !

It is my duty to sacrifice all for them.

The play closes on a long speech by Duke Robert saying farewell to 'life in the forest' in order to do his duty by grasping the rudder of the ship of state, and as the final stage direction asks 'all [to] gather round him', we are left with a visual affirmation of solidarity with the good ruler. 
In George Sand's version there are in effect two courts, one in the 'palais ducal' and one in the forest. In the first act they interact through Jacques who, as a kind of emissary from the exiled Duke, brings Rosalind the 'green' message that her father wishes her 'un printemps aussi vert qua sa vieillesse' (p.135). He also by handing her a letter enables the usurping Duke to accuse her of conspiracy. Celia, who volubly opposes her father's politics, goes into exile partly as a kind of moral blackmail : to make her father repent. This is effective, and in the third act he restores the Dukedom to Duke Senior - in a letter. The emphasis is then thrown on the good Duke's choice : should he leave the green world of retreat and 'revoir le monde' ? It is Jacques, acting as his moral counsellor, who provides the 'raison'. Reminding the good Duke that he has found in the forest 'la sagesse et la science' and that these are gifts of God and should not remain 'stériles' an attitude diametrically opposed to that of Shakespeare's Jacques who advocates the passive good of 'being sad and saying nothing' - Jacques tells him to go forth and teach what he has learned. Translating greenness into the morality of enlightened nineteenthcentury humanitarianism, he concludes with an admonition to let truth, 'cette plante précieuse et rare', discovered in solitude and culled in meditation, become a means of alleviating 'les misères humaines'.

What then has become of Rosalind in these structures of 'habilité' and 'raison'? We are used to seeing her as the key figure in As You Like It, as succinctly put by Anne Barton:

Rosalind in her boy's disguise is the central consciousness of it all: a heroine both involved and dispassionate who seems largely responsible for the structure of that new social order which leaves Arden so hopefully at the end ${ }^{14}$.

In both adaptations it is the exiled Duke who is largely responsible for the structure of that new social order: the sense of an ending rests on his moral rectitude and social concern for his people. Patriarchy and benevolent monarchy seem to be what the two women playwrights make of Shakespeare's green world. Sille Beyer's Rosalind is not really responsible for anything: it is Celia who conceives and arranges her educative encounters with Orlando, only one of which - and a very brief one at that - we witness on stage (though Beyer retained the swooning at the bloody napkin). And it is Touchstone, of all people, who brings 
seen through at first sight by Roland (Orlando), though he pretends that he does not realise who she is ; and this in turn distresses Rosalind, who thinks he cannot really love her if he does not recognise her - which then becomes the main problem in the intrigue to be solved in the dénouement.

Paradoxically, then, the result of 'habilité' replacing convention is to bring home the strength of psychology in Shakespeare's use of convention. Also, paradoxically, the plays become less, not more, feminist. In our own age, feminist criticism has not been altogether comfortable with As You Like It and its heroine, who refuses to be marginalised or victimised. At the heart of the argument in Linda Bamber's Comic Women, Tragic Men lies the notion of comic convention as Shakespeare's (male) way of dealing with the (female) Other: 'the feminine other does not require of her male creator the fatal seriousness he summons up when dealing with the male self. The Other can be contained within the boundaries of her type'. She is 'generic as well as individual' ; she avoids 'choice', 'change and development' ; and selfdiscoveries take place 'at the level of plot, not at the level of individual psychology'. If it is difficult to recognise Rosalind in this, it becomes disturbingly easier once we apply the green world frame. For this critic is, in Jean E. Howard's phrase, 'schooled on the work of Barber and Frye' ; and, as a good pupil, can support her argument on a lesson repeated at length :

In A Natural Perspective Northrop Frye advises us not to look for moral realism in the comedies. Only tragedy, he says, will satisfy those who believe that 'literature's essential function is to illuminate something about life, or reality, or experience, or whatever we call the immediate world outside literature.' ... Comedy, on the other hand, attracts critics like himself: 'In comedy and romance the story seeks its own end instead of holding the mirror up to nature. Consequently comedy and romance are so obviously conventionalized that a serious interest in them soon leads to a serious interest in convention itself ${ }^{19}$.

Beguiling as this is, it simply will not hold against even such minor historical evidence as I have been able to examine in this paper. Versions of As You Like It, which attempt to translate its conventions into something more like 'realism', or 'habilité', help us to query the way 'convention itself' is understood in the 'green world' school. As we have seen, when Shakespeare's con- 
ventions go, the seriousness also goes out of As You Like It as an exploration of love and hatred and a range of other human emotions and attitudes. It would seem that it is because the conventions are so clearly 'imaginary' that they give us a viewpoint from which to see 'real' humanity - men and women, and particularly the latter. The green world of As You Like It is such that the step across to King Lear is shorter than imagined by anyone watching either Life in the Forest or Comme il vous plaira.

Inga-Stina EWBANK
University of Leeds

\section{NOTES}

1. 'The Difficulties of Closure: An Approach to the Problematic in Shakespearian Comedy', in A. R. Braunmuller and J. C. Bulman, eds, Comedy from Shakespeare to Sheridan: Change and Continuity in the English and European Dramatic Tradition (Newark, N.J. and London, 1986), p. 113. - Jean Howard is of course referring in particular to C. L. Barber, Shakespeare's Festive Comedy (Princeton, N. J., 1959) and Northrop Frye, A Natural Perspective (New York, 1965).

2. The texts used and quoted from (by page numbers, as neither has numbered lines) in this paper are, respectively, S.Beyer, Livet $i$ Skoven (Copenhagen, 1850) and Euvres Complètes de George Sand: Théâtre: IV (Paris, 1877), where Comme il vous plaira occupies pp. 111-209. I quote from the Danish text in my own literal translation.

3. It was first performed at the Royal Theatre, Copenhagen, on 1 September 1849. - Sille Beyer (1803-1861) rests her modest fame on altogether 16 translations of plays from the English, French and Spanish, as well as five original (undistinguished) plays, all performed at the Royal Theatre. When, in due course, she was lent a copy of Comme il vous plaira, she found George Sand's ideas very similar to her own but thought the Danish closer than the French to Shakespere's English. See Birgitte Gad, Sille Beyers bearbejdelse av William Shakespeares lystspil (Copenhagen, 1974), p. 39. I owe much of my information about Sille Beyer to Gad's book.

4. 'Shakespeare and the Stoicism of Seneca' (1927), in Selected Essays (new ed., New York, 1950), p. 107. 
5. Letter to William Charles Macready, 10 April 1856: Correspondance de George Sand, ed. Georges Lubin, 20 vols. (Paris, 1964-87), XIll (1978), 575. XIll, 577).

6. Letter to Emile Aucante, 12 April 1856 (Correspondance,

7. Letter to Augustine de Bertholdi, 13 April 1856 (Correspondance, XIll, 579).

8. See reviews quoted in Gad, pp. 70-71.

9. It was performed 40 times at the Royal Theatre, Copenhagen, between 1849 and 1875, and 19 times at the Christiania (i. e. Oslo) Theatre between 1852 and 1878. See Gad, p. 93 and Øyvind Anker, Christiania Theater's Repertoire 1827-99 (Oslo, 1956), p. 58.- Beyer's 'translations' of four other Shakespeare comedies had varying success : Viola (i. e. Twelfth Night) was performed 52 times in Copenhagen, 1847-68, and 12 times in Oslo, 1860-69; Kongens Laege (The King's Physician, i. e. All's Well), 45 times in Copenhagen, 1850-63, and 12 times in Oslo, 1854-69); Lovbud og Lovbrud (i. e. Love's Labour's Lost), 6 times in Copenhagen in 1853 and never in Oslo; Kjaerlighed paa Vildspor (Love on the Wrong Track, i. e. Much Ado about Nothing) 17 times in Copenhagen, 1859-63, and never in Oslo.

10. See J.L. Heiberg's comments on The Taming of the Shrew, quoted in Gad, pp. 26-27.

11. A detailed discussion of what happens to Shakespeare's language would demand another paper. My concern here is mainly with structural and thematic changes.

12. The devotion to visual authenticity is of course a common feature of the European theatre of the period, affecting English Shakespeare as well. For example, Macready's As You Like It at Drury Lane in 1842, with a cast of 97 (78 of whom appeared in the great processional entry of Duke Frederick and his court in Act I), used lavish sets and costumes, evoking France in the fifteenth century. A writer in Theatrical Journal describes how in the final scene 'a fine Maypole rears its flowered crest in proud superiority in the centre of the stage, the groves and trees echo the chirruping of the feathered songsters of the adjoining woods, ... with groupings of joyous peasants and fresh nymphs chorussing the hymns of pastoral joy, in every variety of rich costume, greet Hymen with his love-lit torch'. See Alan S. Downer, The Eminent Tragedian William Charles Macready (Cambridge, Mass., 1966), pp. 215-16.

13. 'The Argument of Comedy', in English Institute Essays, 1948, reprinted in Laurence Lerner, ed., Shakespeare's Comedies : An Anthology of Modern Criticism (Harmondsworth, 1967), p. 321.

14. Anne Barton, 'As You Like It and Twelfth Night: Shakespeare's Sense of an Ending', in David Palmer and Malcolm Bradbury, 
eds., Shakespearian Comedy, Stratford-upon-Avon Studies 14, London, 1972, p. 161.

15. The analogy was not unique to George Sand. See Georg Brandes on how 'Taine, and others after him, have tried to draw a parallel between Jacques and Alceste' (William Shakespeare, rev ed. London, 1917, p. 223). François-Victor Hugo, in the introduction to his translation of As You Like It (1860), argues passionately against any similarity between the two characters (see H. H. Furness, ed., A New Variorum Edition of As You Like It, Philadelphia and London, 1890 , p. 413).

16. Dickens in letter of 22 April 1856, quoted in Edgar Johnson, Charles Dickens: His Tragedy and Triumph. 2 vols, London, 1953, II. 860.

17. See, e. g., Jules Michelet, La femme (Paris, 1859) on the feminine domain.

18. See, e. g., Marjorie Garber, 'The Education of Orlando', in Braunmuller and Bulman, op. cit., pp. 102-12.

19. Comic Women. Tragic Men : A study of Gender and Genre in Shakespeare (Stanford, Calif., 1982) pp. 122-3. 